Original Scientific Paper

Received 10.05.2020.

Approved 04.11.2020.

\title{
FINANCIAL MANAGEMENT AND CONTROL - A New Management Concept in the Context of the Serbian Public Sector
}

\begin{abstract}
Bearing in mind the legislation that sets out the principles of sound financial management, a good understanding of the internal control mechanisms and how they work in practice is necessary. The established level of financial management and control among users of public funds is of unequal quality and has not sufficiently contributed to reducing weaknesses in internal control and raising management responsibility to the optimum level. In order to implement modern management concepts, public companies have to have large access to internal control mechanisms or "tools" to assist in management.Integrated management systems with their modern process approach in business organization and comprehensive and fast processing of information on business changes can significantly contribute to the quality of business control. Research on this issue is based on the fact that the introduction of control standards increases the orderliness and documentation of the system, which significantly contributes to the control of business processes. The aim of this paper is to show that the mutual interdependence of integrated management systems through the overall organization structure with the system of financial management and control, as their final outcome, ensure financial integrity and compliance with policies and procedures and promote effective management processes.
\end{abstract}

Keywords: financial management and control, integrated management systems, risk management, control standards

* Institute of Economics and Law, Belgrade, Serbia; galena.mcl@gmail.com

** JUOŠ „Maršal Tito” Ulcinj; benollunji@gmail.com

*** Faculty of Entrepreneurial Business, University Union „Nikola Tesla”, Belgrade; danijelaparojcic@gmail.com 


\section{INTRODUCTION}

Financial management and control is one of the three pillars of internal financial control of the public sector and it is based on the principles of modern public administration and the responsibilities of executives. This means that every public sector entity must take full responsibility for spending and managing its own budget and ensure that there are adequate controls and safeguards in place. ${ }^{1}$ In order to achieve the full effects and benefits of the implementation of this system, it is necessary to change the awareness of employees in public sector entities in order to consider the benefits of full implementation of the financial management and control system for their work. In this way, the plans defined in the framework of the public administration reform are supported to improve the control environment and assist public funds users in risk assessment, which enables public sector management to be based on effective control mechanisms that mitigate risk and improve the costs effectiveness, efficiency, effectiveness and transparency in the use of public funds, regardless of funding sources.

In this paper the authors have tried to evaluate the contribution of integrated management systems to improving the implementation of financial management and control systems in the Serbian public sector. Both legislative and internal control mechanisms were observed. Legislative control mechanisms are mechanisms that are binding on the basis of positive legal regulations in the Republic of Serbia, while internal control mechanisms are those introduced by the public sector organization itself, on the one hand to improve legal control mechanisms and on the other hand to improve the overall management process.

It is important to emphasize that the system of financial management and control encompasses the entire business and is at the back of every decision and all activities and is a comprehensive system of internal controls, which incorporate within them organizational structure, methods and procedures that cover not only areas of financial nature, but also relate to all operational and strategic goals, creating the preconditions for the public funds user to achieve the defined goals in accordance with the laws, standards and rules with greater economy, efficiency and effectiveness in business.

The authors of this paper start from the fact that in the public sector of Serbia the system of financial management and control is at an early stage of development. The subject of the research is the existence of significant interdependence between the implementation of financial management and control systems and integrated management systems as a modern management concept, seen through the organization and documentation in the overall structure of the organization in the current business practice and with the application of quality standards, but also through the achievement of strategic and operational goals in performing activities.

Priručnik za finansijsko upravljanje i kontrole (2019) Ministarstvo finansija, Republika Srbija Beograd. 


\section{THE CONCEPT OF FINANCIAL MANAGEMENT AND CONTROL}

There are several definitions, but all of them are similar in that they establish that financial management and control encompass the entire system of financial and other controls, including organizational structure, methods and procedures, not only financial systems, but also operational and strategic systems of the organization. These controls, through risk management, reasonably provide assurance that the means (in the right, ethical, economical, effective and efficient manner) are being used to achieve the goals of the enterprise (organization). ${ }^{2}$ In essence, the system of financial management and control is "a philosophy of approach to management" This system is not strictly prescribed by law for companies operating in the Republic of Serbia, but is regulated by law for the public sector. Based on the recommendations of the European Union, the Government of the Republic of Serbia adopts in 2009 the Strategy for the Development of Internal Financial Controls in the Public Sector in the Republic of Serbia. ${ }^{3}$

According to this strategy, the concept of managerial accountability implies that directors of public funds users bear responsibility for the fiscal, managerial and programmatic competencies that have been delegated to them. In the organization for which they are responsible, they are responsible for planning, programming, budgeting / financing plan, budget / financial plan execution, accounting, controls, reporting, archiving and supervision, respectively, and are responsible for setting and achieving the set goals.

Law on the Budget System of the Republic of Serbia, Article $81 .{ }^{4}$ provides that users of public funds are obliged to establish a system of financial management and control in the public sector. The Rulebook on Common Criteria and Standards for Establishing, Functioning and Reporting on the System of Financial Management and Control in the Public Sector ${ }^{5}$ prescribes common criteria and standards for establishing, functioning and reporting on the system of financial management and control in users of public funds. However, the Law on the Budget System does not set any time limits for the establishment of these functions, thus creating space for unequal access to this obligation.

$2 \quad$ Romić, L., Gravorac, S., Šijan, G., Veselinović, B.(2017 ): Implementacija finansijskog upravljanja $i$ kontrole u subjektima javnog sektora-put ka novoj paradigm fiskalne odgovornosti, Ekonomski izazovi br. 11, Univerzitet u Novom Sadu, Ekonomski fakultet u Subotici, Subotica str.77-91

3 Strategija razvoja interne finansijske kontrole u javnom sektoru u Republici Srbiji 20172020, „Sl. Glasnik RS” br. 55/05, 71/05-isp. 101/07, 65/08, 16/11, 68/12-US, 72/12, 7/14-US i $44 / 14$.

4 Zakon o budžetskom sistemu (“Sl.glasnik RS” br. 54/09; 73/10; 101/11; 93/12; 62/13; 63/13; isp. 108/13; 142/14; 68/15-dr.zakon, 99/16; 113/17; 95/18; 31/19 I 72/19).

$5 \quad$ Pravilnik o zajedničkim kriterijumima i standardima za uspostavljanje, funkcionisanje $i$ izveštavanje o sistemu finansijskog upravljanja i kontrole u javnom sektoru, "Sl. glasnik RS" br. 99/11, 106/13. 
The existing legal framework in the Republic of Serbia ensures the implementation of most international standards of internal control. The FMC regulation stipulates that the elements of the Financial Management and Control System are determined in accordance with international internal control standards relating to standards aligned with the International Organization of Supreme Audit Institutions Public Sector Guidelines (INTOSAI).

Adequate financial management and control systems are present for all users of public funds and are primarily designed to ensure compliance with legal and institutional requirements, safeguarding assets against loss, misuse and damage, in addition to ensuring value for money management", also the managerial responsibility at all levels of management and a systematic approach to understanding controls.

The management „value for money” implies that the provision of services to customers and other activities undertaken by the institutions meets the quality standards and is done in a cost-effective, efficient and effective way, in other words to provide quality service at the lowest of possible costs. ${ }^{6}$ The primary responsibility for establishing, maintaining and regularly updating the financial management and control system lies on the director of the public funds user. ${ }^{7}$ The executive director is the "first and last link in the chain of responsibility" however, the "chain of responsibility" is made up of all the managers within the organizational structure.

Managerial responsibility at all levels of management assumes that senior management of each user of public funds is responsible for the way they are managed and how their employees and other stakeholders see it. Based on this model, all executives have to take responsibility for their employees and the scope of controls, in support of general budget user policies

A systematic approach to towards understanding the principles of controls implies that control standards are established in each organization that are explicit and codified, that unambiguous principles are used in their construction, and that they are goal-oriented. According to Mokler ${ }^{8}$ control is a ,systematic" effort to make that planning goals became the control standards, to define feedback, to compare actual results with predefined standards, to determine the magnitude and significance of deviations, and to take appropriate actions that utilize all available resources in an effective and efficient manner to achieve the goals.

Priručnik za finansijsko upravljanje i kontrole (2019) Ministarstvo finansija, Republika Srbija Beograd.

Pravilnik o zajedničkim kriterijumima i standardima za uspostavljanje, funkcionisanje $i$ izveštavanje o sistemu finansijskog upravljanja i kontrole u javnom sektoru, "Sl. glasnik RS" br. 99/11 , 106/13.

$8 \quad$ Mokler, R.(1968): Management Control Models, Holt, New York. 
An important component of the internal control system is the one related to the information and communication system, since the quality of the decisions made by management structures is directly related to the quality of the information on which the decisions are made. The information must be accurate, up-todate, relevant and accessible, which requires efficient communication at all levels in the institution, an appropriate information system, and the implementation of a timely and reliable reporting system. ${ }^{9}$ A well-established system the financial management and control requires constant monitoring of what management structures perform to evaluate, function properly and ensure timely updates. ${ }^{10}$

Monitoring is done through continuous monitoring, self-assessment and internal audit. The financial management and control are not only the responsibility of the organizational units for finance, but it is an integral part of managerial accountability at all levels of management and in all organizational units.

Well-established system of financial management and control are implemented through five interconnected components of internal controls, which include:

- Control environment - must be positive and higher executives must set the tone and, by example, direct employees to respect and perform their duties as best they can;

- $\quad$ Risk management - a strategy that supports the mission and key target entities must be adopted, creating an environment in which the discussion of risks will be part of the ongoing business;

- Control activities - adequate controls must be in place and regularly reviewed to ensure that the internal control system is functioning properly;

- Information and communications - relevant information must be accessible to both employees and the public; it is also necessary to introduce a good two-way communication system;

- Monitoring of controls - users of public funds must regularly assess and monitor risks and controls and, if necessary, make improvements.

It is important to note that no matter how well-designed and operational the management system is, the internal control system cannot provide absolute assurance that the goals of the institution are being achieved, but only a reasonable measure that is a matter of assessment. In making this assessment, managers should identify the risks inherent in activities, programs and projects, assess the risks, and determine the acceptable degree of risk in different circumstances. ${ }^{11}$

Stamatović, M. Maksimović,S.,Tornjanski, A. (2016): Poređenje efikasnosti javnog i privatnog sektora-da li su birokratske procedure izvor neefikasnosti?, Ekonomika, Niš, Vol.62. pp. 111-122.

10 Mazur, B. (2010): Cultural Diversity in Organisational Theory and Practice, Jounal of Intercultural Management, Vol.2. pp. 5-15.

11 Valter,C.(2009): Korporativno upravljanje,merenje performansi i normativna usaglašenost sistema interne kontrole, Data Status, Beograd 
An established system of controls can help an institution achieve its goals, but it is not a substitute for good governance because it only provides information on an institution's progress or insufficient progress, but internal controls cannot achieve goals that depend on management.

An effective financial management and control system should be a structured, permanent and well-documented system designed to identify weaknesses in the controls in place, activities needed to correct those weaknesses, monitor the implementation of necessary corrective actions and periodically assess the adequacy of the FMC. ${ }^{12}$

\subsection{Research Methodological Framework}

The main objective of the research is to show that integrated management systems that represent a way to effectively and efficiently manage an organization are of great importance in the process of implementing internal control mechanisms.

According to the subject of the research, the basic premise of creating a successful business environment is that:

- The system of financial management and control prescribed by law, properly hierarchically established and organized in a way that is accepted by managers and all employees in public sector organizations can contribute to achieving business goals, greater responsibility in spending public funds and strengthening financial discipline.

In relation to the goal of the research, we focused on studying the significance of:

- Established integrated management systems in the existing practice of public sector organizations and degree to which through their process approach contribute to the implementation of financial management and control

- Relationships between the degree of introduction of ISO standards with the system of goal management, orderliness, documentation and control of business processes.

In preparing this research, we used secondary sources of information and the Internet, and certainly the reports of the Central Harmonization Unit at the Ministry of Finance of the Republic of Serbia should be highlighted first. By adopting the Strategy for the Development of Internal Financial Control in the Public Sector in the Republic of Serbia for the period 2017-2020, ${ }^{13}$ the Govern-

12 Priručnik za finansijsko upravljanje i kontrole (2019) Ministarstvo finansija, Republika Srbija, Beograd

13 Strategija razvoja interne finansijske kontrole u javnom sektoru u Republici Srbiji 2017-2020, Sl. Glasnik RS” br. 55/05, 71/05-isp. 101/07, 65/08, 16/11, 68/12-US, 72/12, 7/14-US, 44/14. 
ment of the Republic of Serbia provided strong support for the introduction and strengthening of the IFK system. It also expresses its commitment to implement a series of comprehensive reforms in the area of public finance management in the broadest sense, with the aim of increasing accountability, ensuring sound financial management through improving the efficiency and effectiveness of public resource management.

In the Report of the Ministry of Finance, Central Harmonization Unit of the Republic of Serbia from 2017, states that the financial management and control system, as well as internal audits, are underdeveloped in direct and indirect budget users, and therefore is underdeveloped risk management. The reports received show that the majority of users of public funds have work programs, financial plans, procurement plans and periodic reports. These responses also suggest that public funds users are in the early stages of adopting a risk management methodology and that existing control systems are in place primarily to ensure the legality of the business. Control systems are not sufficiently focused on managing risks that may affect the achievement of other general goals of the organization. It is increase the number of users of public funds who submitted a report for 2017. and it is $23 \%$ higher than in 2016. However, the share of incorrect reports is quite high at $18 \%$ in 2017 , which is somewhat expected because the large number of users submitted reports for the first time. The major gaps identified in completing the report are the following: failure to complete the monitoring, monitoring and evaluation section due to a fundamental misunderstanding of this segment, misunderstanding or non-recognition of certain issues, failure to provide evidence to answer the question, entering data on activities conducted in 2017. instead of showing the state of the FMC system at the end of the reporting year, which negatively reflects the not overall result. ${ }^{14}$

We also used data from the implemented Local Finance Reform Project ${ }^{15}$ launched by the Swiss Secretariat for Economic Affairs (SECO) with the support of the Central Harmonization Unit. This project conducted a survey to determine the current situation of the established FMC system at the Local Government Unit level. The aim of the research was to provide a representative and objective view of the current status of the level of implementation of FMC and the function of Internal Audit in local government units in Serbia. According to a survey of 128 local government units that participated in the survey, 58 (45\%) have established a FMC system, while 70 (55\%) do not. According to this survey, FMCs were more established by cities than by municipalities.

$14 \quad$ Priručnik za finansijsko upravljanje i kontrole (2019) Ministarstvo finansija, Republika Srbija, Beograd.

15 RELOF (2018): Stepen primene finansijskog upravljanja i kontrole i funkcije interne revizije u lokalnim samoupravama i javnim preduzećima osnovanim od strane lokalnih samouprava, SECO, Beograd 
According to the way that FMC was implemented, the research showed that a smaller number of local self-government units introduced this function independently, mainly is developed with the support and constant cooperation with external experts. Also the report to the Central Harmonization Unit, are composed mainly of external experts, and is only forwarded by Local Government Unit. This research also covered issues related to the key challenges that local governments faced during the implementation of FMK, and noted that there was a lack of internal resources (expert staff or resources to hire external experts), and also insufficient awareness of the management, as well as the employees about the importance and the need to establish the FMC; also the failure to decide on the appointment of the Head and the Working Group for the Implementation of the FMC; most employees are not interested in introducing the system; insufficiently educated staff to write procedures and assess risk. ${ }^{16}$

The focus of the analysis of this paper was the heads of finance departments in local governments in Serbia and directors of public companies that should monitor all activities in their organization, as well as whether control activities are functioning properly and whether risks and opportunities are adequately addressed, and all in order to achieve the set goals in the strategic documents as well as in the operational plans. The research was conducted during two lecture cycles at the Belgrade Institute of Economics and Law in collaboration with Sevoi Financial Consulting during May and October 2019 and February 2020. It covered the analysis of the established control mechanisms as well as the entire process of financial management and control in local governments and public companies in Serbia. The results of the analysis are based on the responses of employees in local self-government units from 43 Local Government Unit (54\%), who sent a questionnaire response, out of 80 Local Governement Unit sent to the questionnaire, 34 public companies that responded to the questionnaire as participants in the lecture.The selection of the questions in the questionnaire was made on the basis of taking over some of the questions from the Self-assessment of the Quality of Financial Management and Control, made by the Central Harmonization Unit of the Ministry of Finance of the Republic of Serbia, for the purpose of mandatory annual reporting. The aforementioned questionnaire was designed in a similar fashion to the COSO model for assessing the control environment. ${ }^{17}$

On the basis of the answers received from the questionnaires and interviews conducted with the directors and heads of finance who participated during the two cycles of lectures in the field of FMC, we wanted to evaluate the current level of development of the established internal controls in the Republic of Serbia, and whether the established quality control standards through integrated manage-

$16 \quad$ Ibid, 24.

17 COSO (2010): Report on ERM, preuzeto sa: http://www.coso.org/documents/cososurveyreportfull-web-r6finalforwebposting111710.pdf. Preuzeto: 01/04/2020 
ment systems in current business practices contribute to the easier implementation of financial management and controls.

In planning this research, we have constantly kept in mind that the development of financial management and control is different among users of public funds. Differences certainly arise from the different organizational structure and size of direct and indirect users of budget funds, but not only for these reasons. An important reason can certainly lie in knowing the possibilities, that is, information, but also the willingness and desire to improve the management process. Our goal was to investigate the interdependence and development of integrated management systems in relation to the established system of internal control mechanisms. Because, if the system is regulated, permanent internal control of input and output parameters is carried out, with control of the process flow itself, and with taking of possible corrective measures in accordance with set quality standards, then good business results can be expected.

Starting from the interdependence of the established control mechanisms in correlation with the development of the modern concept of management in the public sector of Serbia, the research sought to determine whether introducing a model of an integrated management system and ISO standards into the entire structure of the organization through a process approach enhances the tidiness and documentation of the entire system.

The introduction of integrated management systems in Serbia began in the early 1990s. Half of the public companies in our sample have implemented some of the standards for most business processes or for all business processes, while $25 \%$ of organizations have not implemented any of the ISO standards.

The most widespread is the application of ISO 9001 in $70 \%$ of the surveyed Public Enterprises, followed by the implementation of ISO 14000 in about a quarter of organizations, ISO 18000 in about $16 \%$ of the organizations in our sample. The most common is their application in the field of technical business, then in the field of commercial business (procurement / sale), and then the following procedures in the field of protection: at work, from fire, environment, and safety. We have slightly fewer procedures in the field of financial management for planning in $30 \%$ and reporting in $32 \%$ of organizations. In doing so, we would like to emphasize that the public companies surveyed are in the field of public communal utilities. When it comes from local self-governments the most common answers are thay do not have integrated management systems or quality standards, the existing internal control systems are characterized mainly by the situation that, by departments of the municipal administration, internal acts have been adopted in which certain business processes or special activities are prescribed, such as in 19 (45\%) of 43 local governments that submitted questionnaire replies. In 14 (33\%) local governments, a system of financial management and control has been established with the cooperation of external experts, but they do not have integrated management systems or quality management standards in place. In $10(22 \%)$ local 
governments that responded to the questionnaire, there are no implemented integrated management systems, no financial management and control, only internal acts have been adopted that prescribe risk management.

In the 19 municipalities surveyed, for which part of the business process is prescribed a way of performing them, in order to ensure their implementation in accordance with the principles of legality, economy, effectiveness and efficiency, there is a serious interest in the implementation and implementation of the FMC system. Also, we have identified for these local governments that no audit trail has been prepared (description of the business process or procedure, description of the activity, the person responsible for carrying out a specific activity in the business process, as well as the deadline within which the activity should be carried out). All instructions should be in written and formal form, not verbal and unofficial, which should be emphasized as a recommendation at all stages of financial management and control implementation.

By introducing elements of corporate governance, i.e. IMS increases the orderliness and documentation of the whole system, thus increasing the awareness of employees and understanding of the importance of implementation of the overall system of internal control mechanisms, all with the aim of increasing the quality of management and achieving the set goals, thus confirming the first hypothesis of this paper

\section{CONSIDERING THE IMPACT OF INTEGRATED SYSTEM MANAGEMENT ON EFFICIENT ESTABLISHMENT OF FMC}

Contemporary management literature deals intensively with the problem of integrated management systems. Different approaches and concepts are present both in theory and in practical realization. By reviewing the topics addressed in the quality principles, it is clear that they relate to the overall functioning of the organization, including other aspects that are often subject to other standards. Therefore, they have a universal character that they give to the whole series of ISO 9000 standards. $^{18}$

Worldwide technical standardization has been established by an international standardization organization, established in 1946 in Geneva. Today, it has 165 members (national standardization organizations), from developed and developing countries, from all five continents. The ISO portfolio includes 19971 developed standards (predominantly technical), which make practical tools to support business worldwide. On the other hand, the standards ISO 9001, ISO 14001 and ISO 22000 are the most well-known and most applied for management systems worldwide, and today they form the framework for business stand-

18 Milekić, M., Bobrek, M. (2015): Integrisani menadžment sistemi, Naučno-stručni skup sa međunarodnim učešćem "QUALITY 2015”, Neum, B\&H, 10. - 13. jun 2015. 
ardization. Within the ISO organization there is an international network of experts working on the development of the ISO model of standards. ${ }^{19}$ The integrated Management System (IMS) is a way to manage an organization effectively and efficiently. Emphasis is placed on the pursuit of process management with the task of transforming the input elements into output elements as efficiently as possible. Therefore, it is necessary for an organization to identify and successfully manage all related activities. „Process approach” involves identifying, classifying, and applying process systems within an organization, together with identifying and interacting those processes, to achieve the desired results. ${ }^{20}$

It is important to note that business processes are not the same as procedures or functions. Procedures describe what needs to be done in a particular situation, and functions are parts of an organization that are assigned specific responsibilities, or work tasks. A business function is an area (field) of work in an organization, a mode of operation that requires similar knowledge and skills (research and development, maintenance, logistics, finance, human resources, accounting). They are practically the result of the specialist division of labor and the traditional organization of the business system. ${ }^{21}$

When recording, analyzing, and improving processes, one should strive to define processes as wide as possible as a whole, and then divide them into subprocesses, since the reverse defined smaller processes will strive for their own efficiency without taking into account the whole. As the goal of every organization should be to provide quality output with the most rational use of imputes globally, the need for standardization has emerged. Based on this need, standards from the area of Quality Management System are created. „The European Community has expressed the same needs with its White Paper, which places particular emphasis on the adoption of many directives for the harmonization of national laws and standards with a deadline of $1992 .{ }^{22}$ The recommendation was to strive for the utmost uniformity of European standards, while respecting national standards and specifics in implementation. ISO / TC 176 Technical Committee of the International Organization for Standardization (ISO) began work in 1979 on ,standardization and harmonization in the field of Quality Management System, Quality Assurance and Appropriate Quality Technologies." The basis was British Standard BS 5750, Part 1 to 6 of 1979. As a result of this work, in 1987 a series of ISO 9000 standards was adopted, accepted by the

19 Majstorović V., Marković M., Kuzmanović D., Maćutić J., Marinković V., Šibalija T., Bekčić S.,Pejović G.(2015): Analiza nivoa poslovne standardizacije u svetu i kod nas, Tehnika, 70 (5). pp. 884-892.

20 Paunović, B. (2016): Ekonomika preduzeća-preduzeće, okruženje i ulaganje, Ekonomski fakultet, Beograd.

${ }^{21}$ Živkov. N. (2012): Integrisani sistemi menadžmenta, Fakultet organizacionih nauka, Beograd

22 https://ec.europa.eu/.../files/bela_knjiga_o_prihodnosti_evrope, Preuzeto:01/04/2020 
European Community under the name „Development of a model of internal control mechanisms in the function of corporate governance" under EN 29000 (the same applies to EFTA members) and other countries in Europe and the World. In our country at that time the standard series was designated JUS ISO $9000 .^{23}$ The new version of the ISO 9000: 2015 series is in line with the already initiated ISO / TC 176 committee process to prescribe a unified structure for management standards, making it easier for them to integrate formally. This process is based on contemporary theoretical concepts of integrated management. Practical models and approaches of this integration are given by the so-called. Annex SL - a document that sets out the basic structure of all management standards. In the future, all ISO MSS (Management System Standard) should be consistent and compatible - they will all look the same and have the same essence. ${ }^{24}$ Standards are implemented one by one, with the ISO 9000 series being taken as the starting point, or multiple standards being applied simultaneously. The aim is to standardize most organizational partial management systems in accordance with the requirements of different international standards.The process of integration of partial management systems can be accomplished in two ways: ${ }^{25}$

- by adding - each management system has its own documentation, which is interconnected,

- including - where documentation of the quality management system is laid as a documentation basis and then expanded according to the requirements of other systems.

The role of integrated standards is to define all process activities, identify all aspects and hazards affecting the environment and the workplace, and more (general safety, security information, etc.) and define measures to reduce all risks. ISO 9001 is a general organizational management standard, applicable to manufacturing, services, public enterprises, government, education. The requirements related to internal audits, non-compliance, corrective and preventive measures and system review (there are still, depending on the standard), are practically the same or very similar to the relevant requirements of ISO 14001 (OHSAS 18001) (OHSAS 18001 (occupational health and safety management) and ISO 22000 (food safety management). ISO 9001 sets out the basic mechanisms to which other standards are based. ${ }^{26}$

23 Vulanović V., Stanivuković D., Kamberović B., Maksimović R., Radaković N., Šilobad M., BekerI., Šević D., Morača S.,Vulanović S., Milisavljević S., Kesić I., Delić M., Brkljač N., (2012): Sistem menadžmenta kvalitetom, UNS-FTN, NoviSad

24 Bobrek, M., Milekić, M. Macanović, K. (2014): Upravljanje kvalitetom (Integrisani sistem upravljanja prema ISO 9001:2015, Saobraćajni fakultet Doboj

25 Đorđević D., Ćoćkalo D.(2007): Upravljanje kvalitetom, TF “Mihajlo Pupin”, Zrenjanin, str. 145.

26 Vulanović V.,Stanivuković D., Kamberović B., Maksimović R., Radaković N., Šilobad M., Beker I., Šević D., Morača S.,Vulanović S., Milisavljević S., Kesić I., Delić M., Brkljač N., 
Considering the integration of the management system, the terms: integration, coordination, parallelism, cooperation, compatibility should be properly understood and used. The benefits of system integration include: improving process performance, internal management methods and interdisciplinary teamwork; greater motivation of the management; fewer multiple audits; increasing customer confidence; cost reduction. ${ }^{27}$ Integration should be planned and implemented in a structured way. Many companies have adopted standardized management systems as a result of external pressure from customers requiring the application of some quality standard or external requirements to establish a health and safety system at work. Integration should be done for the benefit of the business. Therefore, the first step should be to identify the needs of the business. ${ }^{28}$ Also, integrated management systems improve efficiency and effectiveness, contribute to creating synergy by improving communication between organizational units, better cooperation and work in processes. From the top management's point of view, an integrated management system of an organization could be defined as a comprehensive tool that integrates all elements of the business system into a single and complete system of process management in an organization to achieve business goals in accordance with the vision and mission of the organization. ${ }^{29}$ In this sense, from the point of view of our research, the introduction and application of standards of integrated management in public sector organizations significantly contributes to improving the quality of regulation, documentation and control, business processes.

There is a direct correlation between the efficient operation of public enterprises and the established management standards, and it is reflected in the fact that public companies that have and apply quality standards most often achieve better business results. The implementation of integrated management systems and quality management standards in public companies in Serbia is of recent date and has not been sufficiently applied in the operations of public enterprises. The attention of the authors of this paper is focused on the correlation of established management standards with respect to the effective implementation of financial management and control systems. From this point of view, it is necessary to change the current way of managing public companies, establish new management concepts and professionalize management.

(2012): Sistem menadžmenta kvalitetom, UNS-FTN, NoviSad

27 Noble, M. (2000): Organizational Mastery with Integrated Management Systems: Controling the Dragon, John Wiley \& Sons, New York

28 Maksimović, S., Stamatović, M. (2018): Upravljanje rizicima kao deo upravljanja javnim investicionim projektima, 4. Međunarodna naučno stručana konferencija - Inovacije kao pokretač razvoja, Fakultet za primenjeni menadžment, ekonomiju i finansije, Beograd, pp. 4-9.

29 Harrison K. D., Petty J. D. (2002): Systems for Planning and Control in Manufacturing, Newnes 
Based on the conducted research, authors have determined that there is no practice of established management standards in the units of local self-governments that has sent a reply to our questionnaire. The situation in public companies is different, but again the authors emphasize that these are public utility companies that have a legal obligation to establish certain standards (eg. health and hygiene, quality, environmental protection, work safety, etc.).

New management concepts require public companies to continuously monitor the level of customer satisfaction, in order to improve the process of service delivery through feedback regarding certain costs and perceived quality of service. Understanding the use of services and steps required of users, and in order to obtain a quality service product, often leads to ideas - management in accordance with the set goals, ie with a defined mission and vision of the company. All this indicates the intertwining of integrated management systems, established standards and financial management and control, which together form the framework for successful and efficient operation of the public sector.

\section{CONCLUSION}

The implementation and application of financial management and control requires of budget users to actively engage and responsibilities of manager for financial performance. The focus is not only on how much is spent and whether it is within the boundaries of the planned costs, but also on whether the funds are spent on purpose, and what results and effects are achieved by spending those funds.

In addition to the conceptual definition, the paper also presents the components of financial management and control, emphasizing that the implementation of this system requires clearly defined business processes, their duration, input params, as well as outcomes and results. Therefore, it is clear the importance of the introduction and proper implementation of financial management and control, since it directly contributes to the achievement of the set goals through the rationalization of resources.

Financial management and control represent a comprehensive system of business rules and procedures and cover all business transactions, which ensure that risk management assures budget users that they will achieve their business goals, and that they use the funds properly, efficiently and effectively in accordance with legal and other regulations, protecting them from loss, misuse and harm.

The research intent of the authors of this paper was to propose, through the prism of situational, strategic, integrative and controlling dimensions, a good framework for improving the missing elements in the introduction of financial management and control in the Serbian public sector. In this direction, the paper presents the IMS-integrated management system as a process approach to standards, which at 
the same time requires constant compliance with legal regulations and other procedures and is very useful for harmonization of all procedures in the company.

Starting from the concept of financial management and control, integrated management systems can also be considered as one of its elements. Very often, when implementing an IMS module or an ISO standard, the emphasis is on implementing existing processes in the organization, in the spirit of the standard. This achieves its compliance with the „best” world practice. The implementation of the model also introduces existing internal control mechanisms, both in the field of basic processes and in the field of management processes, as well as other support processes.

In this paper, the authors have covered only one part of the elements of financial management and control, and the essential advantage of the proposed models is the comprehensiveness that their application allows, in terms of order and documentation, but also the ability to combine conflicting or sometimes exclusive targets while maintaining the ability to function successfully. In this sense, this approach seeks to strike a balance between short-term goals and long-term stability, between transparency and necessary confidentiality, but also value goals and monitoring.

The results of the research indicate that when creating a sound framework for implementing financial management and control, one must start with a situational analysis, but indicate that a clear attitude is needed when it comes to control standards, as well as formalizing the risk management process. After analyzing the current state of financial management and control in the public sector of Serbia, although there is a slight shift in the implementation of this concept, principles, instructions and recommendations have not been fully adopted, regardless of the legal regulations in this area - since all laws have been adopted and applicable to all users of public funds. The main common problem for all budget users is inadequate administrative capacity. In the coming period, greater attention must be paid to the assessment of training needs in this area by public funds users, and it is also important to carry out continuous situational analysis to identify new needs. Therefore, it is imperative that all relevant actors approach the regulation of this area.

\section{Literature:}

- Bobrek, M., Milekić, M. Macanović, K. (2014): Upravljanje kvalitetom (Integrisani sistem upravljanja prema ISO 9001:2015, Saobraćajni fakultet Doboj.

- COSO (2010): Report on ERM, preuzeto sa: http://www.coso.org/documents/ cososur-veyreportfull-web-r6finalforwebposting111710.pdf

- Čeliković.Z.(2017): Od dobrih smernica do dobre prakse: Novi model korporativnog upravljanja javnim preduzećima u Srbiji, Ekonomske ideje i praksa, Ekonomski fakultet, Beograd, pp. 51-68.

- Đorđević D., Ćoćkalo D.(2007): Upravljanje kvalitetom, TF “Mihajlo Pupin”, Zrenjanin, pp. 145. 
- Harrison K. D., Petty J. D.(2002): Systems for Planning and Control in Manufacturing, Newnes.

- Konsolidovani godišnji izveštaj za 2017.godinu o stanju interne finansijske kontrole u javnom sektoru (2018), Ministarstvo finansija, Sektor za internu kontrolu i reviziju, Beograd.

- Majstorović V., Marković M., Kuzmanović D., Maĉuţić J., Marinković V., Šibalija T., Bekčić S., Pejović G.(2015): Analiza nivoa poslovne standardizacije u svetu i kod nas, Tehnika, 70 (5), pp. 884-892.

- Maksimović, S., Stamatović, M. (2018): Upravljanje rizicima kao deo upravljanja javnim investicionim Projektima, 4. Međunarodna naučno stručana konferencija- Inovacije kao pokretač razvoja, Fakultet za primenjeni menadžment, ekonomiju i finansije, Beograd, str. 4-9.

- Mazur, B. (2010): Cultural Diversity in Organisational Theory and Practice, Jounal of Intercultural Management, Vol.2. pp. 5-15.

- Milekić, M., Bobrek, M.(2015): Integrisani menadžment sistemi, Naučnostručni skup sa međunarodnim učešćem "QUALITY 2015”, Neum, B\&H, 10. - 13. jun.

- Mokler, R.(1968): Management Control Models, Holt, New York.

- Noble, M. (2000): Organizational Mastery with Integrated Management Systems: Controling the Dragon, John Wiley \& Sons, New York.

- Paunović, B. (2016): Ekonomika preduzeća- preduzeće, okruženje i ulaganje, Ekonomski fakultet, Beograd.

- Pravilnik o zajedničkim kriterijumima i standardima za uspostavljanje, funkcionisanje i izveštavanje o sistemu finansijskog upravljanja i kontrole u javnom sektoru, Sl. glasnik RS br. 99/11, 106/13.

- Priručnik za finansijsko upravljanje i kontrole (2019) Ministarstvo finansija, Republika Srbija Beograd.

- RELOF (2018): Stepen primene finansijskog upravljanja i kontrole i funkcije interne revizije u lokalnim samoupravama i javnim preduzećima osnovanim od strane lokalnih samouprava, SECO, Beograd.

- Romić, L., Gravorac, S., Šijan, G.,Veselinović,B. (2017 ): Implementacija finansijskog upravljanja I kontrole u subjektima javnog sektora- put ka novoj paradigm fiskalne odgovornosti, Ekonomski izazovi br. 11, Univerzitet $\mathrm{u}$ Novom Sadu, Ekonomski fakultet u Subotici, Subotica str. 77-91.

- Stamatović, M., Maksimović,S., Tornjanski, A. (2016): Poređenje efikasnosti javnog i privatnog sektora-da li su birokratske procedure izvor neefikasnosti?, Ekonomika, Niš, Vol.62. str. 111-122.

- Strategija razvoja interne finansijske kontrole u javnom sektoru u Republici Srbiji 2017-2020 „Sl. Glasnik RS” br. 55/05, 71/05-isp. 101/07, 65/08, 16/11, 68/12-US, 72/12, 7/14-US i 44/14.

- Valter, C. (2009): Korporativno upravljanje,merenje performansi i normativna usaglašenost sistema interne kontrole, Data Status, Beograd. 
- Vulanović V.,Stanivuković D.,Kamberović B.,Maksimović R.,Radaković N., Šilobad M.,Beker I., Šević D.,Morača S.,Vulanović S., Milisavljević S.,Kesić I., Delić M.,Brkljač N., (2012): Sistem menadžmenta kvalitetom, UNS-FTN, NoviSad.

- Zakon o budžetskom sistemu (“Sl.glasnik RS” br. 54/09;73/10;101/11;93/12;62/13; 63/13; isp.108/13; 142/14; 68/15-dr.zakon, 99/16; 113/17; 95/18; 31/19 I 72/19).

- Živkov. N. (2012): Integrisani sistemi menadžmenta, Fakultet organizacionih nauka, Beograd.

- https://ec.europa.eu/.../files/bela_knjiga_o_prihodnosti_evrope.

Preuzeto:01/04/2020 


\title{
FINANSIJSKO UPRAVLJANJE I KONTROLA - novi koncept upravljanja u kontekstu javnog sektora Srbije
}

\begin{abstract}
Abstrakt: Imajući u vidu zakonodavnu regulativu kojom su propisani principi dobrog finansijskog upravljanja, neophodno je dobro razumevanje unutrašnjih kontrolnih mehanizama $i$ načina na koji oni funkcionišu u praksi. Uspostavljeni nivo finansijskog upravljanja i kontrole kod korisnika javnih sredstava je neujednačenog kvaliteta $i$ nije dovoljno doprineo umanjenju slabosti interne kontrole i podizanju upravljačke odgovornosti do optimalnog nivoa. Savremeni koncepti upravljanja zahtevaju od javnih preduzeća veliki spektar internih kontrolnih mehanizama odnosno „alata“za pomoć pri upravljanju.Integrisani menadžment sistemi svojim savremenim procesnim pristupom u organizaciji poslovanja i sveobuhvatnom i brzom obradom informacija o poslovnim promenama, u značajnoj meri mogu doprineti kvalitetu kontrole poslovanja. Istraživanje ove problematike bazirano je na činjenici da se uvođenjem standarda kontrole povećava uređenost i dokumentovanost sistema, što značajno doprinosi kontroli poslovnih procesa. Cilj rada je da ukaže da međusobno sadejstvo integrisanih menadžment sistema kroz celokupnu strukturu organizacije i sistem finansijskog upravljanja i kontrole kao svoj konačan ishod obezbeđuju finansijski integritet i saglasnost sa politikama i procedurama i promovišu efikasne procese upravljanja.
\end{abstract}

Ključne reči: finansijsko upravljanje i kontrola, integrisani menadžment sistemi, upravljanje rizicima, standardi kontrole 